\title{
A scoping review of side-dress nitrogen recommendation systems and their perspectives in precision agriculture
}

\author{
Martina Corti, Virginia Fassa, Luca Bechini \\ Department of Agricultural and Environmental Sciences - Production, Landscape, Agroenergy, Università \\ degli Studi di Milano, Milano, Italy
}

\begin{abstract}
Highlights
- A scoping review of the main side-dress nitrogen recommendations systems.

- Empirical models are the most common but difficult to generalize.

- Mechanistic models and machine learning rarely consider spatial variability.

- Advanced solutions propose datalalgorithm fusion and study environmental outcomes.

- $\quad$ Future research must maximize the integration of high-resolution monitoring data.
\end{abstract}

\begin{abstract}
A scoping review of the relevant literature was carried out to identify the existing $\mathrm{N}$ recommendation systems, their temporal and geographical diffusion, and knowledge gaps. In total, 151 studies were identified and categorised. Seventy-six percent of $\mathrm{N}$ recommendation systems are empirical and based on spatialised vegetation indices ( $73 \%$ of them); $21 \%$ are based on mechanistic crop simulation models with limited use of spatialized data $(26 \%$ of them); $3 \%$ are based on machine learning techniques with the integration of spatialised and non-spatialised data. Recommendation systems appeared worldwide in 2000; they were often applied in the exact location where calibration had been carried out. Thirty percent of the studies use advanced recommendation techniques, such as sensor/approach fusion (44\%), algorithm add-ons (30\%), estimation of environmental benefits $(13 \%)$, and
\end{abstract}

Correspondence: Martina Corti, Department of Agricultural and Environmental Sciences - Production, Landscape, Agroenergy, Università degli Studi di Milano, via Celoria 2, 20133 Milano, Italy.

E-mail: martina.corti@unimi.it

Key words: Fertilisation; fertiliser amount; sensors; empirical models; mechanistic models; data fusion.

Funding: this research did not receive any specific grant from funding agencies in the public, commercial, or not-for-profit sectors. Martina Corti holds a post-doc grant from Università Degli Studi di Milano.

Received for publication: 5 August 2021.

Revision received: 19 October 2021.

Accepted for publication: 9 December 2021.

(C) Copyright: the Author(s), 2022

Licensee PAGEPress, Italy

Italian Journal of Agronomy 2022; 17:1951

doi:10.4081/ija.2021.1951

This article is distributed under the terms of the Creative Commons Attribution Noncommercial License (by-nc 4.0) which permits any noncommercial use, distribution, and reproduction in any medium, provided the original author(s) and source are credited. multi-objective decisions (13\%). However, some limitations have been identified. For example, empirical systems need specific calibrations for each site, species, and sensor, rarely using soil, vegetation, and weather data together, while mechanistic systems need large input data sets, often non-spatialised. We conclude that $\mathrm{N}$ recommendation systems can be improved by better data and the integration of algorithms.

\section{Introduction}

From the late '90s until now, precision agriculture has come to farmers' attention due to its potential for decreasing economic and environmental costs (Pattey et al., 2001) by applying techniques that increase input use efficiency. Since then, attention has been focused on nitrogen $(\mathrm{N})$, an important growth-limiting factor, the management of which can have significant economic and environmental drawbacks (Olfs et al., 2005). There are different definitions of precision nitrogen management; one involves the concept of precision crop management that applies nitrogen inputs to match the spatial and temporal variability of crop requirements (Taylor and Whelan, 2005). Precision management is based on two steps: the first involves capturing the variability of soil and crop properties (monitoring), and the second is a decisional level where the pieces of information coming from the monitoring phase are used together to quantify the agronomic inputs to apply. So far, the scientific literature has dealt with the monitoring phase by studying proximal and remote sensing techniques suited for crop and soil monitoring (Mulla, 2013) and by evaluating their capacity to estimate N-related crop variables (Corti et al., 2018; Corti et al., 2020). Regarding the second step (decision level), various attempts have been developed to define $\mathrm{N}$ recommendation systems assisted by new technologies (Franzen et al., 2016; Shanahan et al., 2008).

Various recommendation systems have been proposed from the late 1990s until now. Not all of them explicitly address field spatial variability but are worth considering because they estimate recommended $\mathrm{N}$ rates for arable crops. Some of these systems have actually been used in operational conditions, such as the $\mathrm{N}$ mass balance model (Stanford, 1966) that relies on soil measurements together with weather and crop management information (without in-season monitoring); or commercialised algorithms 
that imply the use of optical sensors to retrieve crop status (Francis and Piekielek, 1999; Raun et al., 2005; Holland and Schepers, 2010) and make recommendations for $\mathrm{N}$ mineral fertilizers. Scientific reviews currently available on this topic are rather specific because they focus on the approaches used in selected countries (e.g., Morris et al., 2018) or specifically assess methods based on crop sensors only (Shanahan et al., 2008; Franzen et al., 2016). However, no review has yet to summarise $\mathrm{N}$ recommendation systems state of the art.

Therefore, we carried out a scoping review to: identify, summarise, and review the $\mathrm{N}$ recommendation systems available and their geographical and temporal diffusion; define trends of the development and application of these systems over time, and identify knowledge gaps. The review, which involved the analysis of 354 scientific papers published between 2000 and 2020, was carried out following the Preferred Reporting Items for Systematic Reviews and Meta-Analyses extension for Scoping Reviews (PRISMA-ScR; Tricco et al., 2018). This technique allows mapping available evidence on a topic and identifying the main concepts and knowledge gaps.

Four questions were established at the start of the bibliographic research and used as a guide: i) What recommendation systems are available to support the decision to side-dress $\mathrm{N}$ rate at the field and sub-field scale in arable crops? ii) What are the temporal and geographical diffusion of these methods? iii) What advanced solutions can be identified in $\mathrm{N}$ recommendation systems? iv) What knowledge gaps limit the adoption of these systems?

This paper describes the literature search and its results and discusses the knowledge gaps identified.

\section{Materials and methods}

This work applied a scoping literature review according to the PRISMA method. Figure 1 summarises the search flow of our work. Five steps were carried out to answer the research questions, according to the PRISMA method (Tricco et al., 2018): definition of search strategy, titles and abstract screening, the definition of eligibility criteria, selection of the studies and data collection, and data charting. Each step is presented in the following sub-sections.

\section{Search strategy}

We identified publications in two steps. First, we searched scientific publications in Google Scholar, Scopus, and Web of Science using keywords defining agronomic recommendations ('decision support systems', 'decision support tools') in combination with keywords describing nitrogen-related topics ('nitrogen uptake', 'nitrogen status', 'nitrogen fertilization'), crop monitoring ('remote sensing', 'crop monitoring', 'soil monitoring') and modelling ('crop modelling', 'crop model', 'soil model'). Second, we collected papers written by authors and research groups identified during step one and relevant references cited in papers selected in step one. No time limits were imposed. All the publications found were collected in a unique database.

\section{Titles and abstracts screening}

A total of 354 publications (journal papers, conference papers, articles in trade journals, factsheets, reports, theses, and patents) were collected. Firstly, the publications were analysed by type, and 17 patents were excluded. Then, the remaining 337 publications were analysed by reading their abstracts. After the abstract screen-

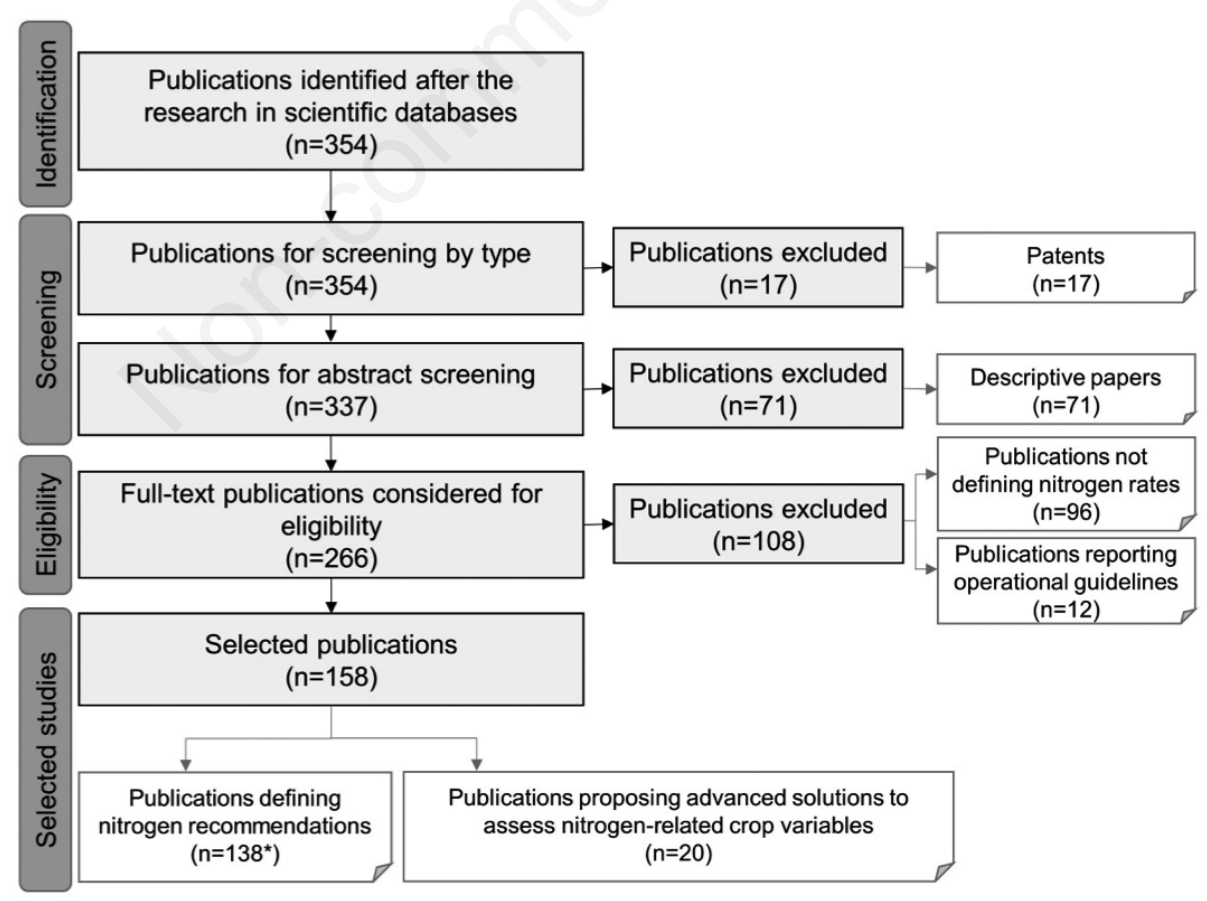

*The number of publications selected was 138 , but the total number of recommendation

systems is 151 because some publications reported more than one system.

Figure 1. Search flow to select the publications analysed in this work. 
ing, 71 publications were eliminated because they included qualitative and descriptive reviews of crop monitoring and precision agriculture techniques $(n=33)$, informative articles $(n=3)$, book chapters $(n=7)$, operational manuals $(n=5)$, and publications related to precision agriculture in general $(n=23)$.

\section{Eligibility criteria}

After title and abstract screening, the publications considered for eligibility were 266 . The full-text papers were then read and evaluated against the eligibility criteria that a paper should either describe a nitrogen recommendation system or propose an advanced solution to estimate an N-related variable. Following this screening, 108 publications were excluded.

\section{Selected studies and data collection}

The publications that passed the eligibility criteria were 158 Each publication was classified following the scheme in Table 1.

After the full-text reading of the selected publications and their classification, the database contained 171 records (some publications studied more than one method): 105 records, coming from 91 publications, describing nitrogen recommendation systems; 46 records from 44 publications describing recommendation systems and advanced solutions; and 20 records from 20 papers only describing advanced solutions.

\section{Data charting}

The information collected in the database was used to answer the research questions. To this aim, data were summarised in tables and figures using Microsoft Excel (2016) and QGIS (3.16 version; QGIS.org, 2021). Data were reported both as the absolute numbers of records and as percentages compared to the total.

\section{Results and discussion}

This section is divided into four sub-sections, each representing one of the research questions established at the beginning of the work.

\section{What are the nitrogen recommendation systems avail- able to support the deciding of side-dress nitrogen rate at the field and sub-field scale in arable crops?}

\section{Algorithms used in nitrogen recommendation systems and their inputs}

The breakdown of the dataset according to the type of algorithms used in the recommendation systems is shown in Table 2.

Empirical models, representing $76 \%$ of the dataset, define $\mathrm{N}$

Table 1. List of characteristics of nitrogen recommendation systems extracted from the selected publications.

\begin{tabular}{|c|c|c|}
\hline Category & Characteristic & Possible values \\
\hline Paper information & $\begin{array}{l}\text { Author } \\
\text { Title } \\
\text { Year } \\
\text { Location }\end{array}$ & \\
\hline $\begin{array}{l}\text { Algorithm used in the nitrogen } \\
\text { recommendation system, } \\
\text { and its application }\end{array}$ & $\begin{array}{l}\text { Algorithm } \\
\text { Is it based on an existing system? } \\
\text { Crop species } \\
\text { Timing of nitrogen application } \\
\text { Description of method } \\
\text { Type of application }\end{array}$ & $\begin{array}{l}\text { Empirical model/Mechanistic crop model/Machine learning } \\
\text { Yes/No } \\
\text { Name of crop species } \\
\text { Development stage when the recommended nitrogen rate shall be applied } \\
\text { The type of sensor, the variable that is estimated and the type of regression } \\
\text { (for empirical methods) or the name of model/machine learning method } \\
\text { Calibration/Nalidation/Comparison with another N recommendation system }\end{array}$ \\
\hline Spatially variable inputs & $\begin{array}{l}\text { Soil sensors } \\
\text { Vegetation sensors } \\
\text { Yield sensors }\end{array}$ & $\begin{array}{l}\text { Yes/No } \\
\text { Yes/No } \\
\text { Yes/No }\end{array}$ \\
\hline Non-spatially variable inputs & $\begin{array}{l}\text { Soil } \\
\text { Vegetation } \\
\text { Weather } \\
\text { Management } \\
\text { Yield } \\
\text { Costs } \\
\text { Nitrogen reference strips }\end{array}$ & $\begin{array}{l}\text { Yes/No } \\
\text { Yes/No } \\
\text { Yes/No } \\
\text { Yes/No } \\
\text { Yes/No } \\
\text { Yes/No } \\
\text { Yes/No }\end{array}$ \\
\hline Advanced solutions & $\begin{array}{l}\text { Type of solution } \\
\text { In the case of data fusion, what } \\
\text { was integrated? }\end{array}$ & $\begin{array}{l}\text { Environmental impact estimation / Multi-objective decision / Data fusion / } \\
\text { Add-ons } \\
\text { E.g., Soil and weather; Crop and weather; Soil, crop and weather, Satellite } \\
\text { data and crop models, Machine learning and empirical model }\end{array}$ \\
\hline
\end{tabular}

Table 2. Breakdown of the dataset according to the algorithm implemented in the nitrogen recommendation system.

\begin{tabular}{lcc} 
Type of algorithm & Records (n) & Records (\%) \\
Empirical model & 115 & 76 \\
Mechanistic crop model & 31 & 21 \\
\hline Machine learning & 5 & 3 \\
Total & 151 & 100
\end{tabular}


recommendations based on empirical functions, from simple regression models to more complex models that need local calibrations. Approaches classified as mechanistic models (21\%) define the $\mathrm{N}$ rate based on a crop and soil simulation model, i.e., computer-based tools that mathematically represent soil-crop-atmosphere dynamics (Wallach et al., 2018). Approaches that define $\mathrm{N}$ rates by applying artificial intelligence, i.e., algorithms and statistical models able to analyse big data to understand underlying patterns and make inferences, were classified as machine learning (3\%). Figure 2 shows the inputs for each group of algorithms. Most empirical models use data from vegetation sensors $(73 \%$ of algorithms), often associated with $\mathrm{N}$ reference strips $(67 \%)$ that define the optimal crop vigour used as a target. Empirical models also use reference information/measurements about the crop (e.g., crop species, developmental stage; $47 \%)$, weather (41\%), soil (37\%) and management (32\%). Mechanistic models need more inputs compared to empirical models. Common inputs of simulation models generally refer to data about the crop (94\%), soil (100\%), weather $(100 \%)$, and management $(100 \%)$ that are needed to represent agro-ecosystem processes mathematically; in only a limited number of cases, mechanistic models made use of remotely sensed data about soil $(3 \%)$ or vegetation $(23 \%)$. Machine learning techniques were used only in five recommendation systems, where spatiallyvariable measurements coming from the crop (60\%) and soil $(20 \%)$ sensors were used together with soil $(80 \%)$, weather $(40 \%)$, and management $(40 \%)$ data by paying more attention to costs (40\%) compared to the other algorithms.

Tables 3 and 4 describe in detail the recommendation systems based on empirical and mechanistic models, respectively.

\section{Empirical models}

The majority of these algorithms (the first which appeared in the literature) are regression models (37\%) using sensor measure- ments applied to vegetation ( $72 \%$ ) to estimate $\mathrm{N}$ rate, $\mathrm{N}$ uptake or to estimate crop yields from which to retrieve, in turn, $\mathrm{N}$ rates, thanks to empirical $\mathrm{N}$ response functions. They have been proposed mainly in the context of cereal crops (maize and wheat) in the USA and EU, and they are characterised by fragmentation of equations and inputs, a factor that contributed to the low level of implementation in operational conditions. The most used methods are from the Oklahoma State University (OSU; Solie et al., 2012)

Empirical model $\square$ Mechanistic model $\square$ Machine learning

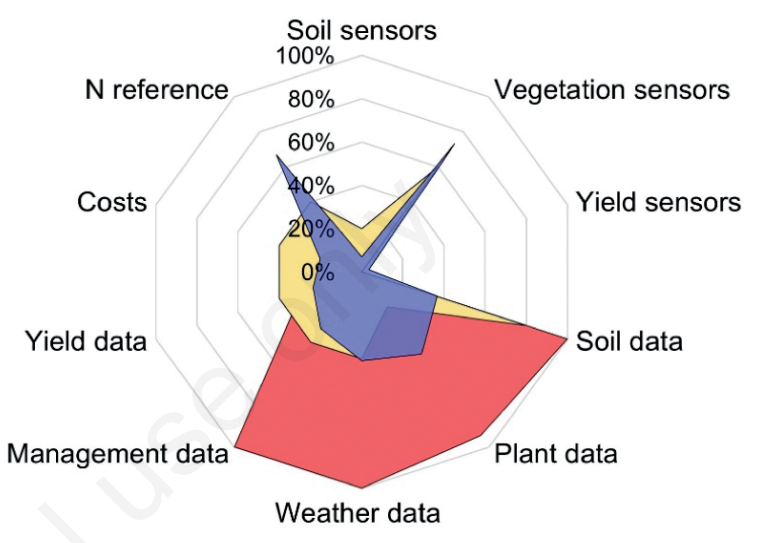

Figure 2. Spider chart showing input data to nitrogen recommendation systems based on empirical models, mechanistic crop models, or machine learning techniques. The data are represented as the percentage of the total records of the group.

Table 3. Details about the algorithms classified as empirical models. The number and percentage of records, inputs used, starting year, geographical distribution, and main crop are indicated for each algorithm. The percentage of records for each category is reported (no number means $100 \%$ ).

\begin{tabular}{|c|c|c|c|c|c|c|c|}
\hline $\begin{array}{l}\text { Reviewed } \\
\text { algorithms }\end{array}$ & $\begin{array}{l}\text { Records } \\
\text { (n) }\end{array}$ & $\begin{array}{l}\text { Records } \\
\text { (\%) }\end{array}$ & $\begin{array}{l}\text { Inputs from } \\
\text { remote sensing }\end{array}$ & $\begin{array}{l}\text { Measured } \\
\text { data inputs }\end{array}$ & $\begin{array}{l}\text { First } \\
\text { year }\end{array}$ & Country* & Crop* \\
\hline $\begin{array}{l}\text { Regression } \\
\text { models }\end{array}$ & 43 & $37 \%$ & $\begin{array}{c}\text { Soil (9\%), Vegetation (72\%), } \\
\text { Yield (2\%) }\end{array}$ & $\begin{array}{c}\text { Soil (23\%), Plant (26\%), } \\
\text { Weather (9\%), Yield (40\%), } \\
\text { Management (26\%), Costs (33\%) }\end{array}$ & 2000 & $\begin{array}{l}\text { USA (56\%), } \\
\text { EU (21\%) }\end{array}$ & $\begin{array}{l}\text { Maize (58\%), } \\
\text { Wheat (26\%) }\end{array}$ \\
\hline $\begin{array}{l}\text { Oklahoma State } \\
\text { University algorithm } \\
\text { and modified } \\
\text { versions }\end{array}$ & 31 & $27 \%$ & $\begin{array}{l}\text { Soil }(9 \%), \\
\text { Vegetation }\end{array}$ & $\begin{array}{c}\text { Soil (15\%), Plant, } \\
\text { Weather, Yield, N reference strips }\end{array}$ & 2006 & $\begin{array}{l}\text { USA (65\%), } \\
\text { China (13\%), } \\
\text { India (13\%) }\end{array}$ & $\begin{array}{l}\text { Maize (42\%), } \\
\text { Wheat (39\%) }\end{array}$ \\
\hline $\begin{array}{l}\text { Nebraska State } \\
\text { University algorithm }\end{array}$ & 12 & $10 \%$ & $\begin{array}{c}\text { Soil (8\%), } \\
\text { Vegetation, Yield (8\%) }\end{array}$ & $\begin{array}{c}\text { Soil, Plant, Management, } \\
\text { N reference strips, Costs (8\%) }\end{array}$ & 2010 & $\begin{array}{l}\text { USA (75\%), } \\
\text { EU (25\%) }\end{array}$ & Maize (75\%) \\
\hline Nutrient Expert & 12 & $10 \%$ & - & $\begin{array}{l}\text { Soil, Plant, Weather (33\%), } \\
\text { Management, Costs (42\%) }\end{array}$ & 2006 & $\begin{array}{c}\text { China (67\%), } \\
\text { Indonesia } \\
\text { and Philippines (17\%) }\end{array}$ & $\begin{array}{l}\text { Maize (42\%), } \\
\text { Rice }(39 \%)\end{array}$ \\
\hline $\begin{array}{l}\text { Chlorophyll meter } \\
\text { algorithms }\end{array}$ & 5 & $4 \%$ & Vegetation & Plant, Management (33\%) & 2006 & USA & Maize (58\%) \\
\hline Virginia Corn Algorithn & hm 3 & $3 \%$ & Vegetation & Weather, $\mathrm{N}$ reference strips & 2011 & USA & Maize (63\%) \\
\hline $\begin{array}{l}\text { Clemson University } \\
\text { algorithm }\end{array}$ & 3 & $3 \%$ & Soil, Vegetation & Plant, Weather, N reference strips & 2011 & USA & $\begin{array}{l}\text { Cotton (63\%), } \\
\text { Maize (37\%) }\end{array}$ \\
\hline MRTN & 3 & $3 \%$ & - & Soil, Plant, Yield, Costs & 2014 & USA & Maize \\
\hline N-mass balance & 3 & $3 \%$ & - & $\begin{array}{l}\text { Soil, Plant, Weather, Management, } \\
\text { Costs (33\%) }\end{array}$ & 2018 & $\begin{array}{l}\text { Brazil (33\%), } \\
\text { Canada (33\%), } \\
\text { Turkey (33\%) } \\
\end{array}$ & Maize (63\%) \\
\hline
\end{tabular}

${ }^{*}$ Countries and crops with more than $10 \%$ of studies. 
and Nebraska State University (NSU; Holland and Schepers 2010). They represent together $37 \%$ of empirical models. Their high diffusion is explained by the fact that they are commercialised using the vegetation sensors GreenSeeker (Trimble Inc., California, USA) and Crop Circle (Holland Scientific, Inc., Nebraska, USA) (Muñoz-Huerta et al., 2013). Both algorithms have been thoroughly reviewed (Samborski et al., 2009; Franzen et al., 2016); therefore, only the basic principles are reported here.

The OSU algorithm relies on two hypotheses: the NDVI (normalised difference vegetation index of the crop measured in-season is a predictor of the yield; the NDVI can also estimate the yield response to $\mathrm{N}$. Thanks to proper calibrations, the measured NDVI is converted into the crop expected yield with no $\mathrm{N}$ added. Then, using local N-rich calibration strips (a small part of the field with no $\mathrm{N}$ limitation from sowing), the crop yield response to $\mathrm{N}$ is estimated so that the yield gap is calculated and the $\mathrm{N}$ rate defined. Initially calibrated for winter wheat in the USA (Raun et al., 2005), it has also been calibrated for maize in the USA (Teal et al., 2006), then generalized (Solie et al., 2012) and tested for several crops (Porter, 2010) and cropping systems (Virginia Corn Algorithm, Thomason et al., 2011; North Dakota State University maize algorithms, Franzen et al., 2014; Clemson University algorithm, Khalilian et al., 2017). The various calibration equations and modifications of the original algorithm are reasons for its wide diffusion.

The NSU algorithm is based on the parametrisation of a quadratic or quadratic-plateau function describing the relationship between $\mathrm{N}$ rate and yield, estimated by the sufficiency index. This index is defined as the ratio between the vegetation index of the actual field and the vegetation index of an N-rich strip (real or virtual, Holland and Schepers, 2013). The producer establishes the maximum $\mathrm{N}$ rate; recommended $\mathrm{N}$ rates are defined depending on the sufficiency index, the parameters of the function, and the estimated contribution from the soil $\mathrm{N}$ pool. The NSU algorithm was proposed for maize in the USA. It accounts for $10 \%$ of the empirical models reviewed here. Other plant-based algorithms have been developed, mainly for maize in the USA, by relating chlorophyll meter readings to recommended $\mathrm{N}$ rates (e.g., Kim et al., 2006). Finally, we also recorded algorithms with no spatialized data inputs: the maximum return to N (MRTN) approach, N-mass balance (Morris et al., 2018), and Nutrient Expert (Pampolino et al., 2012). MRTN is well-known and considers costs, resulting in the optimum economic $\mathrm{N}$ rates; it relies on multiple years and locations of maize $\mathrm{N}$ rate field trials specific for the USA (Melkonian et al., 2008). On the other hand, Nutrient Expert is the most used approach in Asian countries for cereals (rice, maize, and wheat).

Similarly to MRTN, Nutrient Expert has been developed from regional nutrient response studies (Chim et al., 2017). Requirements for macro-nutrients are estimated from the expected yield response to each nutrient, which is the difference between the attainable yield (the one achieved following the best practices) and the nutrient-limited yield (estimated from nutrient omission trials). The inputs needed are data of growing environment characteristics, soil fertility indicators, management, and yields (Pampolino et al., 2012).

\section{Mechanistic and machine learning models}

Mechanistic models are used in $21 \%$ of recorded cases. The Adapt-N model is the most representative, being used in $42 \%$ of studies on maize in the USA. The model incorporates high-resolution weather data and field-specific input information on soil, crop, and management to estimate the recommended $\mathrm{N}$ rate during the growing season. Adapt-N is based on the Precision Nitrogen Management model, which simulates the growth of the crop, and the LEACHN model for the simulation of soil water and $\mathrm{N}$ dynamics (Melkonian et al., 2007). It is a web-based application developed by Cornell University, acquired by Yara International (Yara International ASA, Oslo, Norway), recently adapted to produce $\mathrm{N}$ recommendations for site-specific $\mathrm{N}$ management. Other crop models are used for $\mathrm{N}$ recommendations, sometimes considering spatial variability: STICS and APSIM for maize and wheat (e.g., Bourdin et al., 2017; Puntel et al., 2018, respectively) and CERES for wheat and rice (Cui et al., 2017; Zhang et al., 2018, respectively). When the crop models are spatialised to provide site-specific $\mathrm{N}$ recommendations, the information from vegetation is used to carry out the forcing of crop model (e.g., Guérif et al., 2007), while the use of soil spatialised information from proximal sensing or standard analysis is considered more than in the empirical models (Figure 2). Also, costs are considered more frequently by recommendation systems based on mechanistic models compared to empirical algorithms.

Machine learning techniques are mainly used to integrate empirical models with additional information. In fact, in two of the five publications found, machine learning algorithms were used to integrate weather and soil data that were not considered in the original studies (Ransom, 2018; Ransom et al., 2019). Furthermore, in one study, they were used to define $\mathrm{N}$ recommendation using spatialised vegetation monitoring integrated with soil measured char-

Table 4. Details about the algorithms classified as mechanistic models. The number and percentage of records, inputs used and starting year, geographical distribution, and main crop are indicated for each algorithm. The percentage of records for each category is reported (no number means $100 \%$ ).

\begin{tabular}{|c|c|c|c|c|c|c|c|}
\hline $\begin{array}{l}\text { Reviewed } \\
\text { algorithms }\end{array}$ & $\begin{array}{c}\text { Records } \\
\text { (n) }\end{array}$ & $\begin{array}{c}\text { Records } \\
\text { (\%) }\end{array}$ & $\begin{array}{l}\text { Inputs from } \\
\text { remote sensing }\end{array}$ & $\begin{array}{l}\text { Measured } \\
\text { data inputs }\end{array}$ & $\begin{array}{l}\text { First } \\
\text { year }\end{array}$ & Country* & Crop* \\
\hline Adapt-N & 13 & $42 \%$ & - & $\begin{array}{c}\text { Soil, Plant, Weather, Management, } \\
\text { Costs (23\%) }\end{array}$ & 2007 & USA & Maize \\
\hline APSIM & 5 & $16 \%$ & $\begin{array}{c}\text { Soil (20\%), } \\
\text { Vegetation (40\%) }\end{array}$ & $\begin{array}{c}\text { Soil, Plant, Weather, } \\
\text { Management, Costs (40\%) }\end{array}$ & 2009 & $\begin{array}{l}\text { USA (80\%), } \\
\text { Australia (20\%) }\end{array}$ & $\begin{array}{l}\text { Maize }(80 \%) \\
\text { Wheat (20\%) }\end{array}$ \\
\hline STICS & 4 & $13 \%$ & Vegetation (50\%) & $\begin{array}{c}\text { Soil, Plant, Weather, } \\
\text { Management, Costs (25\%) }\end{array}$ & 2007 & $\begin{array}{l}\text { Canada (50\%), } \\
\text { EU(50\%) }\end{array}$ & $\begin{array}{l}\text { Maize (50\%) } \\
\text { Wheat (50\%) }\end{array}$ \\
\hline CERES & 2 & $6 \%$ & Vegetation (50\%) & $\begin{array}{c}\text { Soil, Plant, Weather, } \\
\text { Management, Costs (50\%) }\end{array}$ & 2017 & China & $\begin{array}{c}\text { Rice (50\%) } \\
\text { Wheat (50\%) }\end{array}$ \\
\hline Others & 7 & $23 \%$ & $\begin{array}{c}\text { Soil (14\%), } \\
\text { Vegetation (29\%) }\end{array}$ & $\begin{array}{c}\text { Soil, Plant, Weather, } \\
\text { Management, Costs (14\%) }\end{array}$ & 2013 & $\begin{array}{l}\text { USA (43\%), } \\
\text { EU (43\%) }\end{array}$ & $\begin{array}{l}\text { Maize }(57 \%) \\
\text { Wheat }(29 \%)\end{array}$ \\
\hline
\end{tabular}

*Countries and crops with more than $10 \%$ of studies. 
acteristics (Tremblay et al., 2010), confirming the trend for deeper data integration.

\section{What is the temporal and geographical diffusion of these methods?}

Figure 3 reports the temporal evolution of the recorded studies.

Empirical models were the first type of algorithms used, with a gradual increase since 2000. The years 2005 and 2010 corresponded to the publication of the OSU algorithm (Raun et al., 2005) and the NSU algorithm (Holland and Schepers, 2010).
Starting from 2012, studies involving Nutrient Expert (Pampolino et al., 2012) were published, contributing to the peak registered in 2017. Mechanistic methods appeared in 2006, but only after 2015 was there a marked increase, with a maximum in 2017. Machine learning reports have increased very recently, from 2017 to 2020 . This evolution is likely linked to the greater availability of large data sets, essential for the algorithm training phase, along with the increase in computing capacity.

The geographical distribution of the recorded studies is shown in Figure 4.

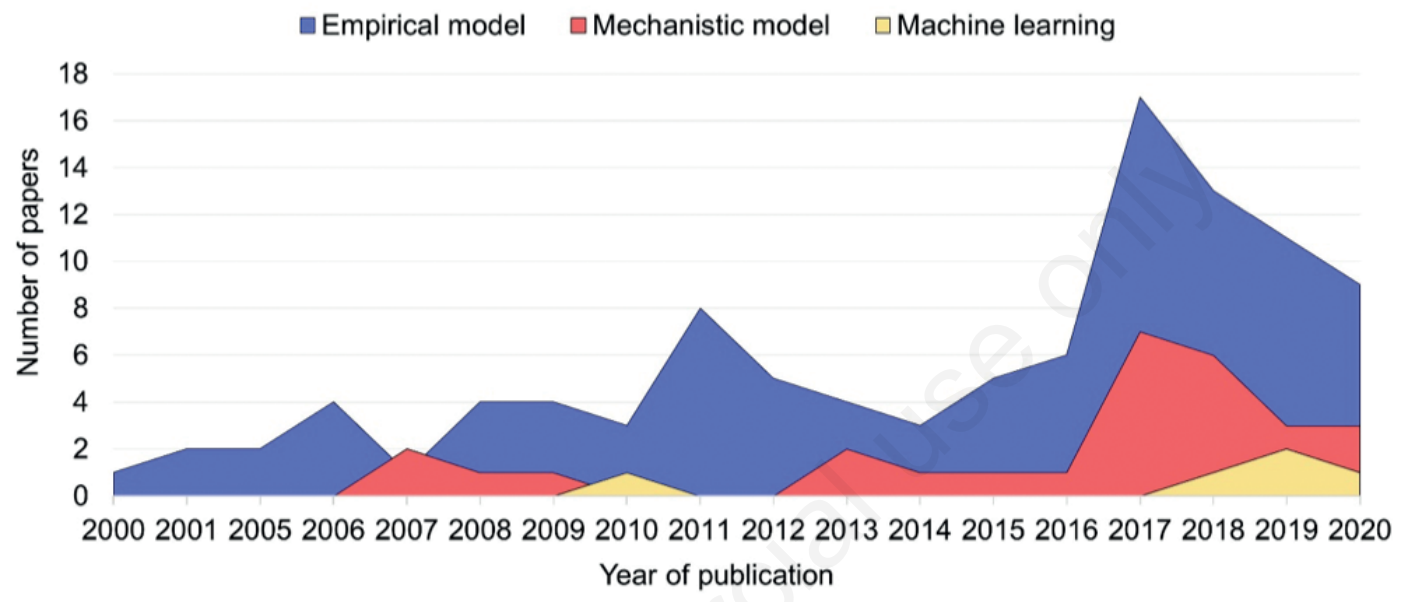

Figure 3. The number of papers describing a nitrogen recommendation system by type of algorithm and by year.

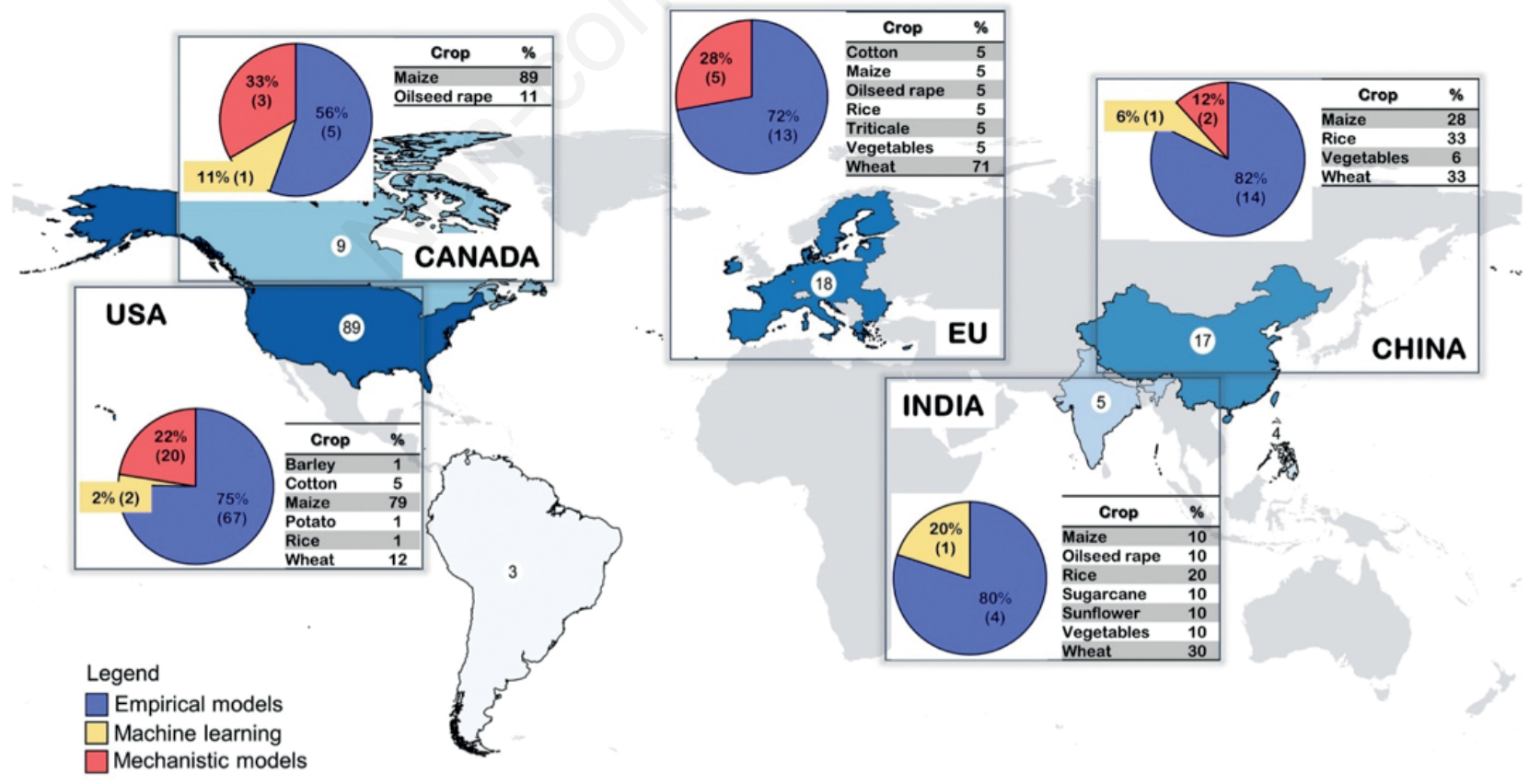

Figure 4. Map of the geographical distribution of the selected nitrogen recommendation systems. Countries with three or more studies are represented in blue (from light to deep blue) with the indication of the number of total studies. For countries with five or more studies, the statistics about the types of algorithms and the crops are presented with a pie chart and a table, respectively. 
Most of the algorithms were developed and used in the USA, where empirical approaches (Raun et al., 2005; Holland and Schepers, 2010; and their variants) were predominant compared to mechanistic models. Also, publications in the EU mostly involved using empirical regression models. However, mechanistic solutions were different: Adapt-N (Melkonian et al., 2008) was the most used in the USA, while in the EU, no specific crop model was predominant (Guérif et al., 2007; Granados et al., 2013; Bourdin et al., 2017; Ravier et al., 2018; Morari et al., 2020; Table 4). In Asian countries, empirical models represented the majority of the approaches used ( $82 \%$ and $80 \%$, respectively), while the use of mechanistic models was very limited; Nutrient Expert (Pampolino et al., 2012) was the most used algorithm, while $44 \%$ of empirical approaches consisted in attempts to calibrate the algorithms developed in the USA. Finally, studies conducted in China and India had the highest number of machine learning approaches (Figure 4).

\section{What advanced solutions can be identified in nitrogen recommendation systems?}

Our presented work also aimed at identifying 'advanced solutions' in defining $\mathrm{N}$ doses. Four solutions were found: sensor/approach fusion, algorithm add-ons, environmental bene- fits, and multi-objective decisions. They were intended as attempts to account for the complexity of data coming from different monitoring systems (i.e., sensor/approach fusion, algorithm add-ons) and for the different impacts of $\mathrm{N}$ fertilization in the agro-ecosystem (i.e., environmental benefits and multi-objective decisions).

Figure 5 shows the abundance of each type of advanced solution, separately for the two datasets: publications with (Figure 5A) and without (Figure 5B) N recommendation systems.

'Sensor/approach fusion' and 'algorithm add-ons' were the most explored solutions ( $40-44 \%$ and $30 \%$, respectively). In the publications proposing an $\mathrm{N}$ recommendation system, 'sensor/approach fusion' mainly consisted in using the proposed algorithm differently for different management zones defined by soil variability ( $60 \%$ of the papers), while in the group of publications with estimates of $\mathrm{N}$-related variables without defining $\mathrm{N}$ doses, it involved the use of more complex combinations such as crop models, machine learning and/or crop monitoring to give better predictions. Only the publications proposing an $\mathrm{N}$ recommendation system were analysed by considering the advanced solutions by algorithm type (Figure 6).

Within publications describing empirical algorithms, 'algorithm add-ons' accounted for $41 \%$ of advanced solutions. These solutions account for the variability not considered in the original
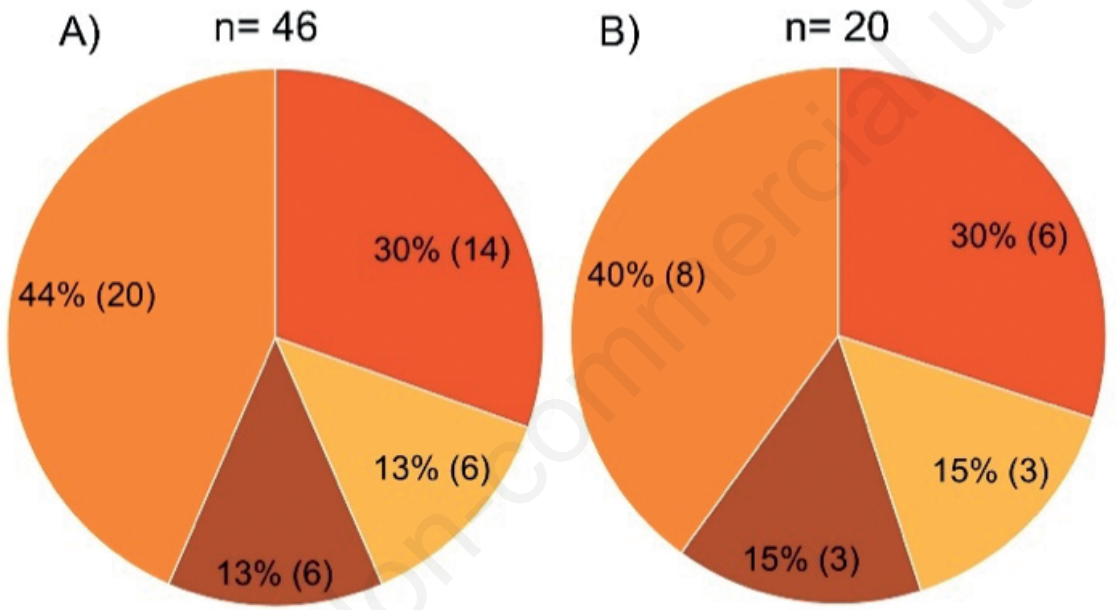

- Algorithm add-ons

Environmental benefits

- Multi-objective decisions

- Sensor/approach fusion

Figure 5. Percentage and number of publications $(\mathrm{n}=66)$ by type of advanced solution adopted. A) Publications with $\mathrm{N}$ recommendation systems; B) Publications without $\mathrm{N}$ recommendation systems.

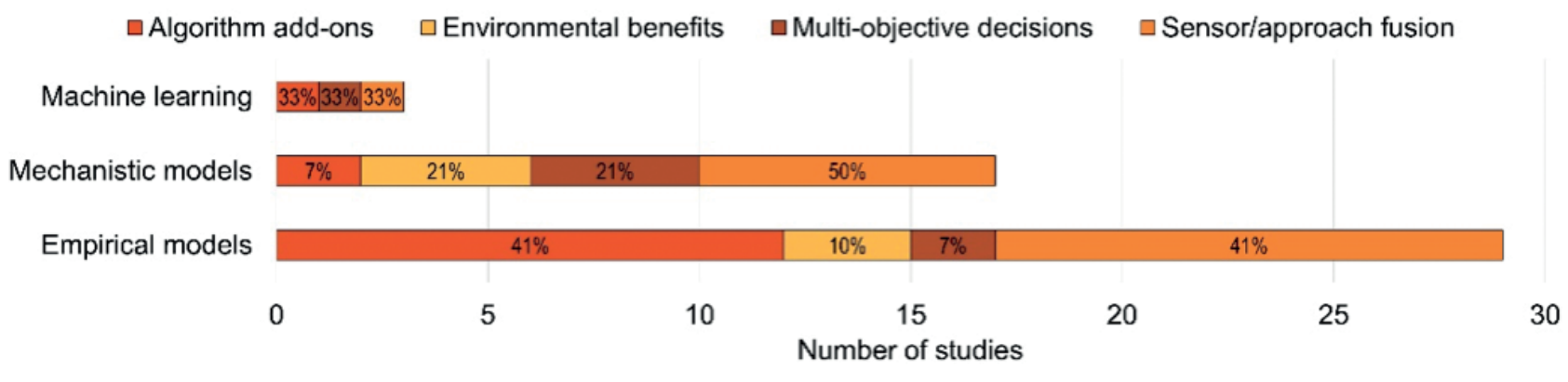

Figure 6. Frequency (\%) of adopting advanced solutions by type of algorithm within the publications describing $\mathrm{N}$ recommendation systems $(n=46)$. 
version of the algorithm or the reference estimation method. In most cases, these solutions used weather- or soil-correcting factors to improve the prediction (e.g., Bean et al., 2018). The advanced solutions involving environmental benefits $(10 \%)$ and multi-objective decisions (7\%) are represented by algorithms explicitly considering $\mathrm{N}$ losses (e.g., Gramig et al., 2017; Lindblom et al., 2017) and taking decisions considering environmental and productive outcomes, respectively. The number of these solutions increased in the most recent years. Conversely to the studies involving empirical models, environmental effects (three studies; 21\%) and multiobjective decisions (three studies; 21\%) (e.g., Mesbah et al., 2018; Moeller et al., 2009) were more frequently addressed with mechanistic models. On the other hand, since mechanistic models already need a high number of input data, the algorithm's 'add-on' strategy was rare (one study, 7\%). Machine learning did not consider environmental outcomes, probably because of the unavailability of a sufficient amount of data to implement the algorithms.

To better clarify what can be done practically to integrate data in recommendation systems, we have identified three examples at increasing levels of complexity: i) combine free remote sensing products with low-cost proximal sensors as inputs to an empirical $\mathrm{N}$ recommendation system ('sensor fusion'); ii) combine empirical $\mathrm{N}$ recommendation systems with machine learning techniques to add knowledge about field properties ('algorithm fusion'); iii) combine soil and crop sensing (either proximal or remote) with a crop model ('high-level data integration').

Nutini et al. (2018) provided an example of the 'sensor fusion' strategy by mixing satellite crop monitoring with smart apps for field scouting and site-specific $\mathrm{N}$ recommendation. They used free Sentinel-2 satellite products to drive field data acquisitions using smartphones as sensors to estimate crop $\mathrm{N}$ requirements (low, medium, high). The proposed solution is cost- and time-effective, widely applicable in operational workflows, but needs calibration of regression curves specific by rice variety group (Paleari et al., 2019), and does not account for soil and weather variability.

Ransom et al. (2019) developed an example of the second approach ('algorithm fusion'). They incorporated soil and weather variables into an empirical $\mathrm{N}$ recommendation system via machine learning, obtaining better estimates of the economically optimum $\mathrm{N}$ rate than the original system and proving that the $\mathrm{N}$ recommendation system takes advantage of added soil and weather variables. However, a limitation of this system is the high number of input data required and the empiricism of the method that could limit its applicability.

Jin et al. (2019) worked with the third option ('high-level data integration'): they combined remote sensing, soil properties, and a crop model to derive $\mathrm{N}$ recommendations. The system retrieved field management zones using yields estimated from satellitederived vegetation index and weather. The crop model APSIM used the state soil national database inputs and simulated yields and $\mathrm{N}$ losses at various $\mathrm{N}$ rates. This system offers high-level data integration and multi-objective decision-making based on economic and environmental outcomes. Its main limitations are the difficulty of yield estimation and accurate retrieval of soil properties for sub-field scales. Therefore, it was not tested on commercial fields.

The three methods have some features in common: i) they need calibration of increasing complexity before they can be applied in operational conditions; ii) they need to consider spatial and temporal field variability; iii) they valorise the large data sets that are being made available by monitoring campaigns.

\section{What are the knowledge gaps that limit the adoption of these systems?}

One of the main issues linked to the limited application of $\mathrm{N}$ recommendation systems in operational conditions is represented by the type of algorithms proposed. Empirical models are the most studied but require calibration whenever they are applied in conditions other than those used for their setup. This is a severe limitation to their adoption. Moreover, these algorithms have been developed to be used with specific optical sensors, making their extension to other sensors cost- and time-consuming. Recent efforts have been made to develop different algorithms based on mechanistic models and machine learning (Morris et al., 2018). They need large inputs datasets because they mathematically or statistically represent the interaction among soil, plants and weather. However, the more significant effort needed to collect input data should correspond to greater applicability of these algorithms. Despite this, their use is frequently limited to research applications. The Adapt-N is the only mechanistic algorithm that has had a commercial interest. It is used for maize in the USA, where it was developed. It was not initially developed for site-specific management (Melkonian et al., 2008).

Moreover, coupling spatialised data with crop models has not yet been fully addressed. The process still has issues related to identifying the correct scale of processes, the selection, and integration of spatialised variables, their use, and the ability of the algorithm to manage uncertainty at different scales. In conclusion, one severe limitation is the poor ability of the algorithms to integrate different data sources. Our analysis showed a trend of developing advanced solutions. However, more efforts could be put in place.

\section{Current and future perspectives}

With the current availability of tools, precision $\mathrm{N}$ management can be carried out using empirical recommendation systems. However, this requires extensive fieldwork for their calibration. For example, specific guidelines are available to calibrate the OSU system (https://nue.okstate.edu/Hand_Held/New_N_Strategy. $\mathrm{htm})$. This involves the implementation of field experiments with monitored no-nitrogen and N-rich strips in different locations. The NDVI is measured at side-dressing for these treatments, and crop yield is measured at harvest. Alternatively, if one wants to use a more mechanistic solution, current crop models can be applied by coupling them with a customised decision support system. For example, Morari et al. (2020) have developed a decision support system based on the SiriusQuality model. When this coupling has been already realised, the system can be applied in different conditions, provided that input data are available, either directly via built-in data recovery functions or provided by the user.

Future research should focus on data and algorithm fusion and on proving the proposed algorithms' economic, agronomic and environmental benefits at farm scales. In fact, nowadays, big data are produced by precision agriculture techniques and Agriculture 4.0, thanks to the use of new soil and crop monitoring techniques together with reference measurements of soil and weather properties. Better integration of several types of data, sensors, and algorithms could be carried out to valorise field data and help the largescale application of algorithms. On the other hand, the level of complexity of the algorithms must meet the knowledge and practical needs of farmers. In fact, some reviewed published works demonstrated that more attention during the research process should be paid to overcoming the problems of implementation of 
$\mathrm{N}$ recommendation systems by developing friendly interfaces (Lindblom et al., 2017). Another factor that will allow wider adoption of $\mathrm{N}$ recommendation systems is their capability to calculate and report the economic, agronomic and environmental advantages of precision compared to conventional management. This will require specific research actions to measure these advantages in the field and disseminate them.

\section{Conclusions}

In the past twenty years, many studies have been carried out to develop $\mathrm{N}$ recommendation systems. Many of them propose empirical $\mathrm{N}$ recommendation algorithms that depend on specific calibration conditions; therefore, they cannot be easily extended to soils, climates, and crops, which differ from those where their calibration was carried out. On the other hand, mechanistic or machine learning algorithms are hardly spatialised enough to provide site-specific $\mathrm{N}$ recommendations. In addition, information about soil properties, crops and weather data, and environmental outcomes is not yet fully integrated, with the result that most current algorithms do not valorise field data. Following the trend already visible in the literature, future research must overcome the specificity of current algorithms and maximize the integration among high-resolution monitoring data sets.

\section{References}

Adamchuk VI, 2013. Theoretical basis for sensor-based in-season nitrogen management. Precis. Agric. 13:403-10.

Adamchuk V, Lacroix R, Shinde S, Tremblay N, Huang H, 2017. An uncertainty-based comprehensive decision support system for site-specific crop management. Adv. Animal Biosci. 8:6259.

Argento F, Anken T, Abt F, Vogelsanger E, Walter A, Liebisch F, 2020. Site-specific nitrogen management in winter wheat supported by low-altitude remote sensing and soil data. Precis. Agric. 22:364-86.

Arnall DB, Abit MJM, Taylor RK, Raun WR, 2016. Development of an NDVI-based nitrogen rate calculator for cotton. Crop Sci. 56:3263-71.

Asebedo AR, 2015. Development of sensor-based nitrogen recommendation algorithms for cereal crops. PhD Thesis, Kansas State University. Available from: https://krex.kstate.edu/dspace/bitstream/handle/2097/19229/AntonioAsebe do2015.pdf?sequence=1 Accessed: October 2021.

Banayo NP, Haefele SM, Desamero NV, Kato Y, 2018. On-farm assessment of site-specific nutrient management for rainfed lowland rice in the Philippines. Field Crops Res. 220:88-96.

Barker DW, Sawyer JE, 2012. Using active canopy sensing to adjust nitrogen application rate in corn. Agron. J. 104:926-33.

Bastos LM, 2019. Evaluation of stabilized fertilizers and crop canopy sensors as next-generation nitrogen management technologies in irrigated corn. Theses, Dissertations, and Student Res. Agron. Horticulture. 165. Available from: https://digitalcommons.unl.edu/agronhortdiss/165 Accessed: October 2021.

Bean GM, Kitchen NR, Camberato JJ, Ferguson RB, Fernandez FG, Franzen DW, Laboski CAM, Nafziger ED, Sawyer JE, Scharf PC, 2018a. Active-optical reflectance sensing corn algorithms evaluated over the United States Midwest Corn
Belt. Agron. J. 110:2552-65.

Bean GM, Kitchen NR, Camberato JJ, Ferguson RB, Fernandez FG, Franzen DW, Laboski CAM, Nafziger ED, Sawyer JE, Scharf PC, 2018b. Improving an active-optical reflectance sensor algorithm using soil and weather information. Agron. J. 110:2541-51.

Berntsen J, Thomsen A, Schelde K, Hansen OM, Knudsen L, Broge N, Hougaard H, Hørfarter R, 2006. Algorithms for sensor-based redistribution of nitrogen fertilizer in winter wheat. Prec. Agric. 7:65-83.

Bhanumathi S, Vineeth M, Rohit N, 2019. Crop yield prediction and efficient use of fertilizers. In: 2019 International Conference on Communication and Signal Processing (ICCSP). IEEE, Chennai, India, pp 0769-73.

Bourdin F, Morell FJ, Combemale D, Clastre P, Guérif M, Chanzy A, 2017. A tool based on remotely sensed LAI, yield maps and a crop model to recommend variable rate nitrogen fertilization for wheat. Adv. Anim. Biosci 8:672-7.

Bowen TR, Hopkins BG, Ellsworth JW, Cook AG, Funk SA, 2005. In-season variable rate $\mathrm{N}$ in potato and barley production using optical sensing instrumentation. pp 141-8 in Western Nutrient Management Conference.

Bragagnolo J, Amado TJC, Bortolotto RP, 2016. Use efficiency of variable rate of nitrogen prescribed by optical sensor in corn. Rev. Ceres. 63:103-11.

Buresh RJ, Castillo RL, Torre JCD, Laureles EV, Samson MI, Sinohin PJ, Guerra M, 2019. Site-specific nutrient management for rice in the Philippines: Calculation of field-specific fertilizer requirements by Rice Crop Manager. Field Crops Res. 239:56-70.

Burns D, 2014. The use of crop sensors and variable rate technology for precision application of nitrogen to cotton. Degree Diss., The University of Tennessee Martin. Available from: https://wwWutm.edu/departments/msanr/_pdfs/burns_researc h_project_final.pdf Accessed: October 2021.

Bushong JT, Mullock JL, Miller EC, Raun WR, Arnall DB, 2016. Evaluation of mid-season sensor based nitrogen fertilizer recommendations for winter wheat using different estimates of yield potential. Prec. Agric. 17:470-87.

Bushong JT, Mullock JL, Miller EC, Raun WR, Klatt AR, Arnall DB, 2016. Development of an in-season estimate of yield potential utilizing optical crop sensors and soil moisture data for winter wheat. Prec. Agric.17:451-69.

Cao Q, Cui Z, Chen X, Khosla R, Dao TH, Miao Y, 2012. Quantifying spatial variability of indigenous nitrogen supply for precision nitrogen management in small scale farming. Prec. Agric. 13:45-61.

Cao Q, Miao Y, Li F, Gao X, Liu B, Lu D, Chen X, 2017. Developing a new Crop Circle active canopy sensor-based precision nitrogen management strategy for winter wheat in North China Plain. Prec. Agric. 18:2-18.

Chim BK, Black T, Davis P, Thomason W, 2017. In-season decision support tools for estimating sidedress nitrogen rates for corn in the Mid-Atlantic Coastal Plain. J. Plant Nutr. 40:281828.

Chuan L, He P, Pampolino MF, Johnston AM, Jin J, Xu X, Zhao S, Qiu S, Zhou W, 2013. Establishing a scientific basis for fertilizer recommendations for wheat in China: Yield response and agronomic efficiency. Field Crops Res. 140:1-8.

Chuan L, Zheng H, Sun S, Wang A, Liu J, Zhao T, Zhao J, 2019. A sustainable way of fertilizer recommendation based on yield response and agronomic efficiency for Chinese cabbage. Sustain. 11:4368. 
Clark JD, Fernández FG, Veum KS, Camberato JJ, Carter PR, Ferguson RB, Franzen DW, Kaiser DE, Kitchen NR, Laboski CA, 2020. Adjusting corn nitrogen management by including a mineralizable-nitrogen test with the preplant and presidedress nitrate tests. Agron. J. 112:3050-64.

Colaço AF, Bramley RGV, 2019. Site-year characteristics have a critical impact on crop sensor calibrations for nitrogen recommendations. Agron. J. 111:2047-59.

Cordero E, Moretti B, Miniotti EF, Tenni D, Beltarre G, Romani M, Sacco D, 2018. Fertilisation strategy and ground sensor measurements to optimise rice yield. Eur. J. Agron. 99:177-85.

Corti M, Cavalli D, Cabassi G, Gallina PM, Bechini L, 2018. Does remote and proximal optical sensing successfully estimate maize variables? A review. Eur. J. Agron. 99:37-50.

Corti M, Marino Gallina P, Cavalli D, Ortuani B, Cabassi G, Cola G, Vigoni A, Degano L, Bregaglio S, 2020. Evaluation of inseason management zones from high-resolution soil and plant sensors. Agronomy 10:1124.

Crowther JD, 2018. Integrating management zones and canopy sensing to improve nitrogen recommendation algorithms. Theses, Dissertations, and Student Research in Agronomy and Horticulture. $135 . \quad$ Available from: https://digitalcommons.unl.edu/agronhortdiss/135 Accessed: October 2021.

Cui B, Huang W, Song X, Ye H, Dong Y, 2017. Study the spatialtemporal variation of wheat growth under different site-specific nitrogen fertilization approaches. pp 316-32 in International Conference on Computer and Computing Technologies in Agriculture. Springer.

Debeljak M, Trajanov A, Kuzmanovski V, Schröder J, Sandén T, Spiegel H, Wall DP, Van de Broek M, Rutgers M, Bampa F, 2019. A field-scale decision support system for assessment and management of soil functions. Front. Environ. Sci. 7:115.

Dehkordi PA, Nehbandani A, Hassanpour-bourkheili S, Kamkar B, 2020. Yield gap analysis using remote sensing and modelling approaches: Wheat in the northwest of Iran. Int. J. Plant Prod. $1-10$.

Dellinger AE, Schmidt JP, Beegle DB, 2008. Developing nitrogen fertilizer recommendations for corn using an active sensor. Agron. J. 100:1546-52.

Edalat M, Naderi R, Egan TP, 2019. Corn nitrogen management using NDVI and SPAD sensor-based data under conventional vs. reduced tillage systems. J. Plant Nutr. 42:2310-22.

van Es H, Ristow A, Nunes MR, Schindelbeck R, Sela S, Davis M, 2020. Nitrate leaching reduced with Dynamic-Adaptive nitrogen management under contrasting soils and tillage. Soil Sci. Soc. Am. J. 84:220-31.

Forrestal PJ, Kratochvil RJ, Meisinger JJ, 2012. Late-season corn measurements to assess soil residual nitrate and nitrogen management. Agron. J. 104:148-57.

Foster A, Atwell S, Dunn D, 2017. Sensor-based nitrogen fertilization for midseason rice production in southeast Missouri. Crop Forage Turfgrass Manage. 3:1-7.

Francis DD, Piekielek MP, 2021. Assessing crop nitrogen needs with chlorophyll meters (SSMG-12). Available from: http://wwWipni.net/publication/ssmg.nsf/0/FE54018670E85C BA852579E50076B0E4/\$FILE/SSMG-12.pdf Accessed: October 2021.

Franzen D, Kitchen N, Holland K, Schepers J, Raun W, 2016. Algorithms for in-season nutrient management in cereals. Agron. J. 108:1775-81.

Franzen DW, Sharma LK, Bu H, 2014. Active optical sensor algorithms for corn yield prediction and a corn side-dress nitrogen rate aid. NDSU Extension Service, North Dakota State University. Available from: https://wwWgoogle.com/url?sa= $\mathrm{t} \& \mathrm{rct}=\mathrm{j} \& \mathrm{q}=\& \mathrm{esrc}=\mathrm{s} \&$ source $=$ web $\& \mathrm{~cd}=\& \mathrm{cad}=\mathrm{rja} \& u a c t=8 \& \mathrm{v}$ ed=2ahUKEwjM4q7jjJLyAhW6wAIHHaw5DYAQFjAAegQI BxAD\&url=https $\% 3 \mathrm{~A} \% 2 \mathrm{~F} \% 2 \mathrm{FwwWag}$. ndsu.edu $\% 2 \mathrm{Fpublicat}$ ions $\% 2$ Fcrops $\% 2$ Fsite-specific-farming-5-active-optical-sensor-algorithms-for-corn-yield-prediction-and-a-corn-sidedress-nitrogen-rate-aid\%2Fsf1176-5.pdf\&usg=AOvVaw 1GoiMQK_h9gWdljuMl5Rq Accessed: October 2021.

Gramig BM, Massey R, Do Yun S, 2017. Nitrogen application decision-making under climate risk in the US Corn Belt. Climate Risk Manage. 15:82-9.

Granados MR, Thompson RB, Fernández MD, Martínez-Gaitán C, Gallardo M, 2013. Prescriptive-corrective nitrogen and irrigation management of fertigated and drip-irrigated vegetable crops using modeling and monitoring approaches. Agric. Water Manage. 119:121-34.

Guérif M, Houlès V, Baret F, 2007. Remote sensing and detection of nitrogen status in crops. Application to precise nitrogen fertilization. In: 4th International Symposium on Intelligent Information Technology in Agriculture $19 \mathrm{p}$.

Han E, Baethgen WE, Ines AV, Mer F, Souza JS, Berterretche M, Atunez G, Barreira C, 2019. SIMAGRI: An agro-climate decision support tool. Comput. Electron. Agric. 161:241-51.

Hawkins JA, Sawyer JE, Barker DW, Lundvall JP, 2007. Using relative chlorophyll meter values to determine nitrogen application rates for corn. Agron. J. 99:1034-40.

He P, Xu X, Chuan L, Johnston A, 2006. Evaluation of a new fertilizer recommendation approach to improve nitrogen use efficiency across small-holder farms in China. In: Proceedings of the 2016 International Nitrogen Initiative Conference, Melbourne, Australia. pp 4-8. http://agronomyaustraliaproceeding s.org/images/sampledata/ini2 $016 / \mathrm{pdf}$ papers/INI2016_He_Ping.pdf Accessed: October 2021.

Holland KH, Schepers JS, 2010. Derivation of a variable rate nitrogen application model for in-season fertilization of corn. Agron. J. 102:1415-24.

Holland KH, Schepers JS, 2013. Use of a virtual-reference concept to interpret active crop canopy sensor data. Prec. Agric. 14:7185.

Holmes A, Jiang G, 2018. Increasing profitability \& sustainability of maize using site-specific crop management in New Zealand. In: Proceedings of the 14th International Conference on Precision Agriculture, Montreal, Quebec, Canada.

Holzapfel CB, Lafond GP, Brandt SA, Bullock PR, Irvine RB, James DC, Morrison MJ, May WE, 2009. Optical sensors have potential for determining nitrogen fertilizer topdressing requirements of canola in Saskatchewan. Canad. J. Plant Sci. 89:411-25.

Jin Z, Archontoulis SV, Lobell DB, 2019. How much will precision nitrogen management pay off? An evaluation based on simulating thousands of corn fields over the US Corn-Belt. Field Crops Res. 240:12-22.

Jin Z, Prasad R, Shriver J, Zhuang Q, 2017. Crop model-and satellite imagery-based recommendation tool for variable rate $\mathrm{N}$ fertilizer application for the US Corn system. Prec. Agric. 18:779-800.

Jones JR, 2013. Improving early season sidedress nitrogen rate prescriptions for corn. Thesis, Virginia Tech.

Kabir M, Nur S, Chung S-O, Jang B-E, Kim Y-J, Lee G-J, Lee KH, Okayasu T, Inoue E, 2019. Variable fertilizer recommendation for grass production by image-based growth status. J. Faculty Agric. Kyushu Univ. 64:145-55. 
Kapp-Junior C, Caires EF, Guimarães AM, Auler AC, 2020. Regression modeling nitrogen fertilization requirement for maize crop by combining spectral reflectance and agronomic efficiency. J. Plant Nutr. 1-12.

Karki TB, 2013. Yield prediction and nitrogen recommendation in maize using normalized difference vegetation index. Agron. J. Nepal 3:82-8.

Karyotis K-V, Gülbahar N, Panagopoulos A, 2018. A two-dimensional nitrogen fertilization model for irrigated crops in Turkey. Am. Sci. Res. J. Engine. Technol. Sci. (ASRJETS) 41:319-32.

Khalilian A, Rogers NG, Williams PB, Han YJ, Nafchi AM, Maja JM, Marshall MW, Payero JO, 2017. Sensor-based algorithm for mid-season nitrogen application in corn. Open J. Soil Sci. 7:278-87.

Khoshnevisan B, Rafiee S, Pan J, Zhang Y, Liu H, 2020. A multicriteria evolutionary-based algorithm as a regional scale decision support system to optimize nitrogen consumption rate; A case study in North China plain. J. Cleaner Prod. 256:120213.

Kim Y, Reid JF, Han S, 2006. On-the-go nitrogen sensing and fertilizer control for site-specific crop management. Int. J. Agric. Biol. Engine. 7:18-26.

Kitchen NR, Sudduth KA, Drummond ST, Scharf PC, Palm HL, Roberts DF, Vories ED, 2010. Ground-based canopy reflectance sensing for variable-rate nitrogen corn fertilization. Agron. J. 102:71.

Krienke BT, 2011. Evaluation of algorithm thresholds for crop canopy sensor-based in-season nitrogen application in corn. Theses, Dissertations, and Student Research in Agronomy and Horticulture. $32 . \quad$ Available from: https://digitalcommons.unl.edu/agronhortdiss/32 Accessed: October 2021.

Laboski CAM, Camberato JJ, Sawyer JE, 2014. Evaluation of Adapt-N in the corn belt. Proceedings of the 44th North Central Extension-Industry Soil Fertility Conference, Des Moines, IA, USA, 30:7-14. Available from: http://lib.dr.iastate.edu/agron_conf/52 Accessed: October 2021.

Lawes RA, Oliver YM, Huth NI, 2019. Optimal nitrogen rate can be predicted using average yield and estimates of soil water and leaf nitrogen with infield experimentation. Agron. J. 111:1155-64.

Lekakis E, Perperidou D, Kotsopoulos S, Simeonidou P, 2020. Producing mid-season nitrogen application maps for arable crops, by combining Sentinel-2 satellite images and agrometeorological data in a decision support system for farmers. The Case of NITREOS. In: International Symposium on Environmental Software Systems. Springer, pp 102-14.

Levitan N, Gross B, 2018. Utilizing collocated crop growth model simulations to train agronomic satellite retrieval algorithms. Remote Sensing 10:1968.

Lindblom J, Lundström C, Ljung M, Jonsson A, 2017. Promoting sustainable intensification in precision agriculture: review of decision support systems development and strategies. Prec. Agric. 18:309-31.

Linna P, Narra N, Grönman J, 2019. Intelligent data service for farmers. pp. 1072-52019 in 42nd International Convention on Information and Communication Technology, Electronics and Microelectronics (MIPRO), IEEE.

Liu C, Liu Y, Li Z, Zhang G, Chen F, 2017. A novel way to establish fertilization recommendations based on agronomic efficiency and a sustainable yield index for rice crops. Sci. Rep. $7: 1-8$.

Loo MK, 2018. Building the foundation for the CropManage
Nitrogen Fertilizer Decision Support Framework to guide Hawai'i's vegetable production systems. PhD Thesis, University of Hawai'i at Mānoa. Available from: https://scholarspace.manoa.hawaii.edu/bitstream/10125/62809/2018-05ms-loo.pdf Accessed: October 2021.

Lu J, Miao Y, Shi W, Li J, Hu X, Chen Z, Wang X, Kusnierek K, 2020. Developing a proximal active canopy sensor-based precision nitrogen management strategy for high-yielding rice. Remote Sensing 12:1440.

Lukina EV, Freeman KW, Wynn KJ, Thomason WE, Mullen RW, Stone ML, Solie JB, Klatt AR, Johnson GV, Elliott RL, Raun WR, 2001. Nitrogen fertilization optimization algorithm based on in-season estimates of yield and plant nitrogen uptake. J. Plant Nutr. 24:885-98.

Mack CJ, 2006. Validation of nitrogen calibration strip technology for prescribing accurate topdress nitrogen fertilizer. $\mathrm{PhD}$ Thesis, Oklahoma State University.

Makowski D, Wallach D, 2001. How to improve model-based decision rules for nitrogen fertilization. Eur. J. Agron. 15:197208.

Makowski D, Wallach D, Meynard J-M, 2001. Statistical methods for predicting responses to applied nitrogen and calculating optimal nitrogen rates. Agron. J. 93:531-9.

Marinello F, Gatto S, Bono A, Pezzuolo A, 2017. Determination of local nitrogen loss for exploitation of sustainable precision agriculture: approach description. pp. 713-718 in Proceedings of the International Scientific Conference, Latvia University of Agriculture.

McFadden BR, Brorsen BW, Raun WR, 2018. Nitrogen fertilizer recommendations based on plant sensing and Bayesian updating. Prec. Agric. 19:79-92.

McNunn G, Heaton E, Archontoulis S, Licht MA, VanLoocke A, 2019. Using a crop modeling framework for precision costbenefit analysis of variable seeding and nitrogen application rates. Front. Sustain. Food Syst. 3:108.

Melkonian JJ, Van Es HM, DeGaetano AT, Joseph L, 2008. ADAPT-N: Adaptive nitrogen management for maize using high-resolution climate data and model simulations. In: Proceedings of the 9th International Conference on Precision Agriculture. Available from: https://cpb-use1.wpmucdn.com/blogs.cornell.edu/dist/8/6785/files/2016/06/ Prec-Ag-Conf-2008-Melkonian-van-Es-uhaslu.pdf_Accessed: October 2021

Melkonian J, Van Es HM, DeGaetano AT, Sogbedji JM, Joseph L, Bruulsema T, 2007. Application of dynamic simulation modeling for nitrogen management in maize. pp. 14-22 in Managing Crop Nutrition for Weather. International Plant Nutrition Institute Publication, Peachtree Corners, GA, USA.

Mesbah M, Pattey E, Jégo G, 2017. A model-based methodology to derive optimum nitrogen rates for rainfed crops - a case study for corn using STICS in Canada. Comput. Electron. Agric. 142:572-84.

Mesbah M, Pattey E, Jégo G, Didier A, Geng X, Tremblay N, Zhang F, 2018. New model-based insights for strategic nitrogen recommendations adapted to given soil and climate. Agron. Sustain. Develop. 38:36.

Miller EC, Bushong JT, Raun WR, Abit MJM, Arnall DB, 2017. Predicting early season nitrogen rates of corn using indicator crops. Agron. J. 109:2863-70.

Moeller C, Asseng S, Berger J, Milroy SP, 2009. Plant available soil water at sowing in Mediterranean environments - Is it a useful criterion to aid nitrogen fertiliser and sowing decisions? Field Crops Res. 114:127-36. 
Montealegre JPG, Wortmann C, Ferguson R, Shaver T, Schepers J, 2019. Nitrogen sidedress directed by corn canopy reflectance for manured fields. Agron. J. 111:2453-61.

Montealegre JPG, Wortmann C, Schepers J, Little R, 2019. Applied organic nitrogen: Pre-plant and in-season estimation of corn nitrogen uptake. Field Crops Res. 241:107577.

Morari F, Zanella V, Gobbo S, Bindi M, Sartori L, Pasqui M, Mosca G, Ferrise R, 2021. Coupling proximal sensing, seasonal forecasts and crop modelling to optimize nitrogen variable rate application in durum wheat. Precis. Agric. 22:75-98.

Morris TF, Murrell TS, Beegle DB, Camberato JJ, Ferguson RB, Grove J, Ketterings Q, Kyveryga PM, Laboski CA, McGrath JM, 2018. Strengths and limitations of nitrogen rate recommendations for corn and opportunities for improvement. Agron. J. 110:1-37.

Mulla DJ, 2013. Twenty five years of remote sensing in precision agriculture: Key advances and remaining knowledge gaps. Biosyst. Engine. 114:358-71.

Muñoz-Huerta R, Guevara-Gonzalez R, Contreras-Medina L, Torres-Pacheco I, Prado-Olivarez J, Ocampo-Velazquez R, 2013. A review of methods for sensing the nitrogen status in plants: advantages, disadvantages and recent advances. Sensors 13:10823-43.

Nasielski J, Grant B, Smith W, Niemeyer C, Janovicek K, Deen B, 2020. Effect of nitrogen source, placement and timing on the environmental performance of economically optimum nitrogen rates in maize. Field Crops Res. 246:107686.

Niemeyer C, 2020. Improving corn nitrogen fertilizer recommendations for Ontario with rainfall effects on crop nitrogen demand. Thesis, the University of Guelph, Canada. UG ETD Template (uoguelph.ca) Accessed: October 2021.

Nigon TJ, Yang C, Mulla DJ, Kaiser DE, 2019. Computing uncertainty in the optimum nitrogen rate using a generalized cost function. Comput. Electron. Agric. 167:105030.

Nutini F, Confalonieri R, Crema A, Movedi E, Paleari L, Stavrakoudis D, Boschetti M, 2018. An operational workflow to assess rice nutritional status based on satellite imagery and smartphone apps. Comput. Electron. Agric. 154:80-92.

Olfs H-W, Blankenau K, Brentrup F, Jasper J, Link A, Lammel J, 2005. Soil- and plant-based nitrogen-fertilizer recommendations in arable farming. J. Plant Nutr. Soil Sci. 168:414-31.

Oliveira LF, Scharf PC, Vories ED, Drummond ST, Dunn D, Stevens WG, Bronson KF, Benson NR, Hubbard VC, Jones AS, 2013. Calibrating canopy reflectance sensors to predict optimal mid-season nitrogen rate for cotton. Soil Sci. Soc. Am. J. 77:173-83.

Osmond D, Austin R, Shelton S, van Es H, Sela S, 2018. Evaluation of Adapt-N and realistic yield expectation approaches for maize nitrogen management in North Carolina. Soil Sci. Soc. Am. J. 82:1449-58.

Oyinbo O, 2019. Site-specific nutrient management advice and agricultural intensification in maize-based systems in Nigeria. PhD Thesis, KU Leuven. Available from: https://irias.kuleuven.be/2870930?limo=0 Accessed: October 2021.

Pahlmann I, Böttcher U, Kage H, 2017. Developing and testing an algorithm for site-specific $\mathrm{N}$ fertilization of winter oilseed rape. Comput. Electron. Agric. 136:228-37.

Paiao GD, Fernández FF, Spackman JA, Kaiser DE, Weisberg S, 2020. Ground-based optical canopy sensing technologies for corn-nitrogen management in the Upper Midwest. Agron. J. 112:2998-3011.

Paleari L, Movedi E, Vesely F, Thoelke W, Tartarini S, Foi M, Boschetti M, Nutini F, Confalonieri R, 2019. Estimating crop nutritional status using Smart Apps to support nitrogen fertilization. A case study on paddy rice. Sensors 19:981.

Pampolino MF, Witt C, Pasuquin JM, Johnston A, Fisher MJ, 2012. Development approach and evaluation of the Nutrient Expert software for nutrient management in cereal crops. Comput. Electron. Agric. 88:103-10.

Pattey E, Strachan IB, Boisvert JB, Desjardins RL, McLaughlin NB, 2001. Detecting effects of nitrogen rate and weather on corn growth using micrometeorological and hyperspectral reflectance measurements. Agric. Forest Meteorol. 108:85-99.

Porter WM, 2010. Sensor based nitrogen management for cotton production in coastal plain soils. Thesis, Clemson University. Available from: https://tigerprints.clemson.edu/cgi/viewcontent.cgi? article $=1914 \&$ context $=$ all theses Accessed: October 2021.

Preza Fontes G, Bhattarai R, Christianson LE, Pittelkow CM, 2019. Combining environmental monitoring and remote sensing technologies to evaluate cropping system nitrogen dynamics at the field-scale. Front. Sustain. Food Syst. 3:8.

Puntel LA, Sawyer JE, Barker DW, Thorburn PJ, Castellano MJ, Moore KJ, VanLoocke A, Heaton EA, Archontoulis SV, 2018. A systems modeling approach to forecast corn economic optimum nitrogen rate. Front. Plant Sci. 9:436.

Purba J, Sharma RK, Jat ML, Thind HS, Gupta RK, Chaudhary OP, Chandna P, Khurana HS, Kumar A, Uppal HS, 2015. Sitespecific fertilizer nitrogen management in irrigated transplanted rice (Oryza sativa) using an optical sensor. Prec. Agric. 16:455-75.

Quebrajo L, Pérez-Ruiz M, Rodriguez-Lizana A, Agüera J, 2015. An approach to precise nitrogen management using hand-held crop sensor measurements and winter wheat yield mapping in a Mediterranean environment. Sensors 15:5504-17.

Qin Z, Myers DB, Ransom CJ, Kitchen NR, Liang SZ, Camberato JJ, Carter PR, Ferguson RB, Fernandez FG, Franzen DW, 2018. Application of machine learning methodologies for predicting corn economic optimal nitrogen rate. Agron. J. 110:2596-607.

Ransom CJ, 2018. Evaluating and improving corn nitrogen fertilizer recommendation tools across the US Midwest. PhD Thesis, University of Missouri-Columbia. Available from: https://mospace.umsystem.edu/xmlui/bitstream/handle/10355/ 66184/research.pdf?sequence=1 Accessed: October 2021.

Ransom CJ, Kitchen NR, Camberato JJ, Carter PR, Ferguson RB, Fernández FG, Franzen DW, Laboski CA, Myers DB, Nafziger ED, 2019. Statistical and machine learning methods evaluated for incorporating soil and weather into corn nitrogen recommendations. Comput. Electron. Agric. 164:104872.

Ransom CJ, Kitchen NR, Camberato JJ, Carter PR, Ferguson RB, Fernández FG, Franzen DW, Laboski CA, Nafziger ED, Sawyer JE, 2020. Corn nitrogen rate recommendation tools' performance across eight US Midwest corn belt states. Agron. J. 112:470-92.

Raun WR, Solie JB, Stone ML, Martin KL, Freeman KW, Mullen RW, Zhang H, Schepers JS, Johnson GV, 2005. Optical sensorbased algorithm for crop nitrogen fertilization. Commun. Soil Sci. Plant Anal. 36:2759-81.

Ravier C, Jeuffroy MH, Gate P, Cohan JP, Meynard JM, 2018. Combining user involvement with innovative design to develop a radical new method for managing $\mathrm{N}$ fertilization. Nutr. Cycling Agroecosyst. 110:117-34.

Rhezali A, Purcell LC, Roberts TL, Greub CE, 2018. Predicting nitrogen requirements for maize with the dark green color index under experimental conditions. Agron. J. 110:1173-9. 
Roberts DF, 2009. An integrated crop-and soil-based strategy for variable-rate nitrogen management in corn. Theses, Dissertations, And Student Research In Agronomy And Horticulture: 3. Available from: https://digitalcommons.unl. edu/agronhortdiss/3 Accessed: October 2021.

Roberts DC, Brorsen BW, Solie JB, Raun WR, 2011. The effect of parameter uncertainty on whole-field nitrogen recommendations from nitrogen-rich strips and ramped strips in winter wheat. Agric. Syst. 104:307-14.

Roberts DF, Ferguson RB, Kitchen NR, Adamchuk VI, Shanahan JF, 2012. Relationships between soil-based management zones and canopy sensing for corn nitrogen management. Agron. J. 104:119-29.

Rogers NG, Williams PB, Nafchi AM, Han YJ, Maja JMJ, Payero JO, Khalilian A, 2017. Development of a sensor-based algorithm to determine the mid-season nitrogen requirements in deficit irrigated corn production. pp. 1 in 2017 ASABE Annual International Meeting. Am. Soc. Agric. Biol. Engine.

Rutan J, Steinke K, 2017. Determining corn nitrogen rates using multiple prediction models. J. Crop Improv. 31:780-800.

Ruiz Diaz DA, Hawkins JA, Sawyer JE, Lundvall JP, 2008. Evaluation of in-season nitrogen management strategies for corn production. Agron. J. 100:1711-9.

Sala F, Boldea M, Rawashdeh H, Nemet I, 2015. Mathematical model for determining the optimal doses of mineral fertilizers for wheat crops. Pak. J. Agric. Sci. 52:609-17.

Samborski SM, Gozdowski D, Stępień M, Walsh OS, Leszczyńska E, 2016. On-farm evaluation of an active optical sensor performance for variable nitrogen application in winter wheat. Eur. J. Agron. 74:56-67.

Samborski SM, Gozdowski D, Walsh OS, Kyveryga P, Stępień M, 2017. Sensitivity of sensor-based nitrogen rates to selection of within-field calibration strips in winter wheat. Crop Pasture Sci. 68:101-14.

Samborski SM, Tremblay N, Fallon E, 2009. Strategies to make use of plant sensors-based diagnostic information for nitrogen recommendations. Agron. J. 101:800-16.

Sawyer JE, 2013. Comparison of the MRTN and Adapt-N derived $\mathrm{N}$ rates for corn. Agronomy Conference Proceedings and Presentations. 41. Available from: http://lib.dr.iastate.edu/agron_conf/41 Accessed: October 2021.

Scharf PC, Kitchen NR, Sudduth KA, Davis JG, Hubbard VC, Lory JA, 2005. Field-scale variability in optimal nitrogen fertilizer rate for corn. Agron. J. 97:452-61.

Scharf PC, Shannon DK, Palm HL, Sudduth KA, Drummond ST, Kitchen NR, Mueller LJ, Hubbard VC, Oliveira LF, 2011. Sensor-based nitrogen applications out-performed producerchosen rates for corn in on-farm demonstrations. Agron. J. 103:1683-91

Schmidt J, Beegle D, Zhu Q, Sripada R, 2011. Improving in-season nitrogen recommendations for maize using an active sensor. Field Crops Res. 120:94-101.

Schmidt JP, Sripada RP, Beegle DB, Rotz CA, Hong N, 2011. Within-field variability in optimum nitrogen rate for corn linked to soil moisture availability. Soil Sci. Soc. Am. J. 75:306-16.

Schwalbert RA, Amado TJC, Reimche GB, Gebert F, 2019. Finetuning of wheat (Triticum aestivum, L.) variable nitrogen rate by combining crop sensing and management zones approaches in southern Brazil. Prec. Agric. 20:56-77.

Sela S, van Es HM, Moebius-Clune BN, Marjerison R, MoebiusClune D, Schindelbeck R, Severson K, Young E, 2017.
Dynamic model improves agronomic and environmental outcomes for maize nitrogen management over static approach. J. Environ. Qual. 46:311-9.

Sela S, Van Es HM, Moebius-Clune BN, Marjerison R, Melkonian J, Moebius-Clune D, Schindelbeck R, Gomes S, 2016. Adapt$\mathrm{N}$ outperforms grower-selected nitrogen rates in Northeast and Midwestern United States strip trials. Agron. J. 108:1726-34.

Sela S, Woodbury PB, van Es HM, 2018. Dynamic model-based N management reduces surplus nitrogen and improves the environmental performance of corn production. Environ. Res. Lett. 13:054010.

Sela S, Woodbury PB, Marjerison R, van Es HM, 2019. Towards applying $\mathrm{N}$ balance as a sustainability indicator for the US Corn Belt: realistic achievable targets, spatio-temporal variability and policy implications. Environ. Res. Lett. 14:064015.

Shahhosseini M, Martinez-Feria RA, Hu G, Archontoulis SV, 2019. Maize yield and nitrate loss prediction with machine learning algorithms. Environ. Res. Lett. 14:124026.

Shanahan JF, Kitchen NR, Raun WR, Schepers JS, 2008. Responsive in-season nitrogen management for cereals. Comput. Electron. Agric. 61:51-62.

Shiratsuchi LS, 2011. Integration of plant-based canopy sensors for site-specific nitrogen management. Theses, Dissertations, and Student Research in Agronomy and Horticulture. 36. Available from: https://digitalcommons.unl.edu/agronhortdiss/36 Accessed: October 2021.

Solari F, Shanahan JF, Ferguson RB, Adamchuk VI, 2010. An active sensor algorithm for corn nitrogen recommendations based on a chlorophyll meter algorithm. Agron. J. 102:1090-8.

Solie JB, Monroe AD, Raun WR, Stone ML, 2012. Generalized algorithm for variable-rate nitrogen application in cereal grains. Agron. J. 104:378-87.

Stamatiadis S, Schepers JS, Evangelou E, Tsadilas C, Glampedakis A, Glampedakis M, Dercas N, Spyropoulos N, Dalezios NR, Eskridge K, 2018. Variable-rate nitrogen fertilization of winter wheat under high spatial resolution. Prec. Agric. 19:570-87.

Stanford G, 1966. Nitrogen requirements of crops for maximum yield. Agric. Anhydrous Ammonia Technol. Use 237-57.

Tagarakis AC, Ketterings QM, 2018. Proximal sensor-based algorithm for variable rate nitrogen application in maize in northeast USA. Comput. Electr. Agricu. 145:373-8.

Tauer LW, 2000. Determining the optimal amount of nitrogen to apply to corn using the Box-Cox Functional Form. No. 6422016-43990. Available from: https://ecommons.cornell.edu/ bitstream/handle/1813/57745/Cornell_Dyson_wp0006.pdf?se quence $=1 \&$ isAllowed=y Accessed: October 2021 .

Taylor J, Whelan B, 2005. A general introduction to precision agriculture. Australian Center For Precision Agriculture. Available from: http://wwWagriprecisione.it/wp-content/uploads/ 2010/11/general_introduction_to_precision_agriculture.pdf Accessed: October 2021.

Teal RK, Tubana B, Girma K, Freeman KW, Arnall DB, Walsh O, Raun WR, 2006. In-season prediction of corn grain yield potential using normalized difference vegetation index. AgronJ. 98:1488-94.

Thind HS, Kumar A, Choudhary OP, Gupta RK, Vashistha M, 2017. Site-specific fertilizer nitrogen management using optical sensor in irrigated wheat in the Northwestern India. Agric. Res. 6:159-68.

Thomason WE, Phillips SB, Davis PH, Warren JG, Alley MM, Reiter MS, 2011. Variable nitrogen rate determination from plant spectral reflectance in soft red winter wheat. Prec. Agric. 12:666-81. 
Thompson LJ, Ferguson RB, Kitchen N, Franzen DW, Mamo M, Yang H, Schepers JS, 2015. Model and sensor-based recommendation approaches for in-season nitrogen management in corn. Agron. J. 107:2020-30.

Thompson LJ, Puntel LA, 2020. Transforming unmanned aerial vehicle (UAV) and multispectral sensor into a practical decision support system for precision nitrogen management in corn. Remote Sensing 12:1597.

Tremblay N, Bouroubi MY, Panneton B, Guillaume S, Vigneault P, Bélec C, 2010. Development and validation of fuzzy logic inference to determine optimum rates of $\mathrm{N}$ for corn on the basis of field and crop features. Precis. Agric. 11:621-35.

Trevisan RG, Shiratsuchi LS, Bullock DS, Martin NF, 2019. Improving yield mapping accuracy using remote sensing. Preprints 2019:2019010287.

Tricco AC, Lillie E, Zarin W, O’Brien KK, Colquhoun H, Levac D, Moher D, Peters MDJ, Horsley T, Weeks L, Hempel S, Akl EA, Chang C, McGowan J, Stewart L, Hartling L, Aldcroft A, Wilson MG, Garritty C, Lewin S, Godfrey CM, Macdonald MT, Langlois EV, Soares-Weiser K, Moriarty J, Clifford T, Tunçalp Ö, Straus SE, 2018. PRISMA Extension for Scoping Reviews (PRISMA-ScR): Checklist and Explanation. Ann. Intern. Med. 169:467-73.

Tubaña BS, Arnall DB, Walsh O, Chung B, Solie JB, Girma K, Raun WR, 2008. Adjusting midseason nitrogen rate using a sensor-based optimization algorithm to increase use efficiency in corn. J. Plant Nutr. 31:1393-419.

van Es H, Ristow A, Nunes MR, Schindelbeck R, Sela S, Davis M, 2020. Nitrate leaching reduced with Dynamic-Adaptive nitrogen management under contrasting soils and tillage. Soil Sci. Soc. Am. J. 84:220-31.

Vian AL, Bredemeier C, Turra MA, Giordano CP da S, Fochesatto E, Silva JA da, Drum MA, 2018. Nitrogen management in wheat based on the normalized difference vegetation index (NDVI). Ciência Rural 48.

Villalobos FJ, Delgado A, Lopez-Bernal A, Quemada M, 2020. FertiliCalc: A decision support system for fertilizer management. Int. J. Plant Prod. 1-10.

Vizzari M, Santaga F, Benincasa P, 2019. Sentinel 2-based nitrogen VRT fertilization in wheat: Comparison between traditional and simple precision practices. Agronomy 9:278.

Wallach D, Makowski D, Jones JW, Brun F, 2018. Working With Dynamic Crop Models: Methods, Tools And Examples For Agriculture And Environment. Academic Press, London, UK, 613.

Walsh OS, Shafian S, Christiaens RJ, 2018. Evaluation of sensorbased nitrogen rates and sources in wheat. Int. J. Agron. 2018:5670479.

Wang H, 2017. Crop assessment and monitoring using optical sensors. PhD Thesis, Kansas State University. Available from: https://krex.k-state.edu/dspace/bitstream/handle/2097/
38224/HuanWang2017.pdf?sequence=3 Accessed: October 2021.

Wang X, Miao Y, Dong R, Chen Z, Guan Y, Yue X, Fang Z, Mulla DJ, 2019. Developing active canopy sensor-based precision nitrogen management strategies for maize in Northeast China. Sustainability 11:706.

Wiatrak P, Khalilian A, Wallace D, Henderson W, Hallmen R, 2008. Incorporating soil electric conductivity and optical sensing technology to develop a site-specific nitrogen application for corn in South Carolina. pp 107-12 in Proceeding of the 2008 Southern Conservation Agricultural Systems Conference. Citeseer.

Williams P, 2018. Development of a sensor-based, variable-rate fertigation technique for overhead irrigation systems. All Dissertations. 2176. Available from: https://tigerprints.clemson.edu/all_dissertations/2176 Accessed: October 2021.

Xu X, He P, Pampolino MF, Li Y, Liu S, Xie J, Hou Y, Zhou W, 2016. Narrowing yield gaps and increasing nutrient use efficiencies using the Nutrient Expert system for maize in Northeast China. Field Crops Res. 194:75-82.

Xu X, He P, Qiu S, Pampolino MF, Zhao S, Johnston AM, Zhou W, 2014. Estimating a new approach of fertilizer recommendation across small-holder farms in China. Field Crops Res. 163:107.

Xu X, He P, Yang F, Ma J, Pampolino MF, Johnston AM, Zhou W, 2017. Methodology of fertilizer recommendation based on yield response and agronomic efficiency for rice in China. Field Crops Res. 206:33-42.

Xue L, Li G, Qin X, Yang L, Zhang H, 2014. Topdressing nitrogen recommendation for early rice with an active sensor in south China. Precis. Agric. 15:95-110.

Yang F, Xu X, Ma J, He P, Pampolino MF, Zhou W, 2017. Experimental validation of a new approach for rice fertiliser recommendations across smallholder farms in China. Soil Res. 55:579-89.

Yuan M, Ruark MD, Bland WL, 2017. Adaption of the AmaizeN model for nitrogen management in sweet corn (Zea mays L.). Field Crops Res. 209:27-38.

Zhang JJ, He P, Xu XP, Wang YL, Jia LL, Cui RZ, Wang HT, Zhao SC, Ullah S, 2017. Nutrient expert improves nitrogen efficiency and environmental benefits for summer maize in China. Agron. J. 109:1082-90.

Zhang J, Miao Y, Batchelor WD, Lu J, Wang H, Kang S, 2018. Improving high-latitude rice nitrogen management with the CERES-rice crop model. Agronomy 8:263.

Zhao X, Nafziger ED, Pittelkow CM, 2017. Nitrogen rate strategies for reducing yield-scaled nitrous oxide emissions in maize. Environ. Res. Letters 12:124006.

Zillmann E, Graeff S, Link J, Batchelor WD, Claupein W, 2006. Assessment of cereal nitrogen requirements derived by optical on-the-go sensors on heterogeneous soils. Agron. J. 98:682-90. 